\title{
Intrauterine Growth Restriction. Guideline of the German Society of Gynecology and Obstetrics (S2k-Level, AWMF Registry No. 015/080, October 2016) \author{
(S2k-Level, AWMF-Registernummer 015/080, Oktober 2016)
} \\ Intrauterine Wachstumsrestriktion. Leitlinie der DGGG
}

Authors

Sven Kehl ${ }^{1}$, Jörg Dötsch ${ }^{2}$, Kurt Hecher ${ }^{3}$, Dietmar Schlembach ${ }^{4}$, Dagmar Schmitz ${ }^{5}$, Holger Stepan ${ }^{6}$, Ulrich Gembruch ${ }^{7}$

Affiliations

1 Frauenklinik, Universitätsklinikum Erlangen, Erlangen, Germany

$\Theta$ Deutsche Version unter: https://doi.org/10.1055/s-0043-118908

2 Klinik und Poliklinik für Kinder- und Jugendmedizin, Universitätsklinikum Köln, Köln, Germany

3 Klinik für Geburtshilfe und Pränatalmedizin, Universitätsklinikum Hamburg-Eppendorf, Hamburg, Germany

4 Klinik für Geburtsmedizin, Vivantes Klinikum Neukölln, Berlin, Germany

5 Institut für Geschichte, Theorie und Ethik der Medizin, Uniklinik RWTH Aachen, Aachen, Germany

6 Abteilung für Geburtsmedizin, Universitätsklinikum Leipzig, Leipzig, Germany

7 Abteilung für Geburtshilfe und Pränatale Medizin, Universitätsklinikum Bonn, Bonn, Germany

Key words

IUGR, growth restriction, guideline

Schlüsselwörter

IUGR, Wachstumsrestriktion, Leitlinie

received $\quad 19.8 .2017$

revised 19.8.2017

accepted 25.8.2017

\section{Bibliography}

DOI https://doi.org/10.1055/s-0043-118908

Geburtsh Frauenheilk 2017; 77: 1157-1173 @ Georg Thieme

Verlag KG Stuttgart · New York | ISSN 0016-5751

Correspondence

Prof. Dr. med. habil. Sven Kehl

Frauenklinik, Universitätsklinikum Erlangen

Universitätsstraße 21-23, 91054 Erlangen, Germany

sven.kehl@gmail.com

\section{ABSTRACT}

Aims The aim of this official guideline published and coordinated by the German Society of Gynecology and Obstetrics (DGGG) was to provide consensus-based recommendations obtained by evaluating the relevant literature for the diagnostic treatment and management of women with fetal growth restriction.

Methods This S2k guideline represents the structured consensus of a representative panel of experts with a range of different professional backgrounds commissioned by the Guideline Committee of the DGGG.

Recommendations Recommendations for diagnostic treatment, management, counselling, prophylaxis and screening are presented.

\section{ZUSAMMENFASSUNG}

Ziel Das Ziel dieser offiziellen Leitlinie, die von der Deutschen Gesellschaft für Gynäkologie und Geburtshilfe (DGGG) publiziert und koordiniert wurde, ist es, durch die Evaluation der relevanten Literatur einen konsensbasierten Überblick über die Diagnostik und das Management der intrauterinen Wachstumsrestriktion zu geben.

Methoden Diese S2k-Leitlinie wurde durch einen strukturierten Konsens von repräsentativen Mitgliedern verschiedener Professionen im Auftrag der Leitlinienkommission der DGGG entwickelt.

Empfehlungen Es werden Empfehlungen zur Diagnostik, Management, Beratung, Prophylaxe und Screening gegeben. 


\section{Guideline Information}

\section{Guidelines Program of the DGGG, OEGGG and SGGG}

Information on the program is provided at the end of the article.

\section{CITATION FORMAT}

Intrauterine Growth Restriction. Guideline of the German Society of Gynecology and Obstetrics (S2k-Level, AWMF Registry Number 015/080, October 2016). Geburtsh Frauenheilk 2017; 77: 1157-1173

\section{Guideline documents}

The complete long version (in German), a PDF slideshow for PowerPoint presentations and a summary of the conflicts of interest of all the authors is available on the AWMF homepage under: http://www.awmf.org/leitlinien/detail/I/015-080.html

\section{Guideline authors}

The following professional and scientific societies/working groups/organizations/associations have stated their interest in contributing to the compilation of the guideline text and participating in the consensus conference and have sent representatives to the consensus conference ( $\vee$ Table 1 ).

- Table 1 Authors and representatives: participation of the target user group.

\begin{tabular}{|c|c|}
\hline $\begin{array}{l}\text { Author } \\
\text { Mandate holder }\end{array}$ & $\begin{array}{l}\text { DGGG working group/AWMF/non AWMF } \\
\text { professional association/organization/society }\end{array}$ \\
\hline \multicolumn{2}{|c|}{ Lead author and/or coordinating author: } \\
\hline $\begin{array}{l}\text { PD Dr. med. } \\
\text { Sven Kehl }\end{array}$ & $\begin{array}{l}\text { German Society of Gynecology and Obstetrics } \\
\text { (Deutsche Gesellschaft für Gynäkologie und } \\
\text { Geburtshilfe e.V. [DGGG]) }\end{array}$ \\
\hline \multicolumn{2}{|c|}{ Other lead authors: } \\
\hline $\begin{array}{l}\text { PD Dr. med. } \\
\text { Dagmar Schmitz }\end{array}$ & $\begin{array}{l}\text { German Academy for Ethics in Medicine } \\
\text { (Akademie für Ethik in der Medizin [AEM]) }\end{array}$ \\
\hline $\begin{array}{l}\text { PD Dr. med. } \\
\text { Dietmar } \\
\text { Schlembach }\end{array}$ & $\begin{array}{l}\text { Working Group Hypertension in Pregnancy/ } \\
\text { Gestosis (Arbeitsgemeinschaft Schwangerschafts- } \\
\text { hochdruck/Gestose e.V. [AG Gestose]) }\end{array}$ \\
\hline $\begin{array}{l}\text { Prof. Dr. med. } \\
\text { Kurt Hecher }\end{array}$ & $\begin{array}{l}\text { Germany Society for Ultrasound in Medicine } \\
\text { (Deutsche Gesellschaft für Ultraschall in der Medizin } \\
\text { e.V. [DEGUM]) }\end{array}$ \\
\hline $\begin{array}{l}\text { Prof. Dr. med. } \\
\text { Holger Stepan }\end{array}$ & $\begin{array}{l}\text { German Society of Gynecology and Obstetrics } \\
\text { (Deutsche Gesellschaft für Gynäkologie und } \\
\text { Geburtshilfe e.V. [DGGG]) }\end{array}$ \\
\hline $\begin{array}{l}\text { Prof. Dr. med. } \\
\text { Jörg Dötsch }\end{array}$ & $\begin{array}{l}\text { German Society for Pediatric and Adolescent } \\
\text { Medicine (Deutsche Gesellschaft für Kinder- und } \\
\text { Jugendmedizin e. V. [DGK]]) and German Society } \\
\text { for Neonatology and Pediatric Intensive Care } \\
\text { (Gesellschaft für Neonatologie und Pädiatrische } \\
\text { Intensivmedizin [GNPI]) }\end{array}$ \\
\hline $\begin{array}{l}\text { Prof. Dr. med. } \\
\text { Ulrich Gembruch }\end{array}$ & $\begin{array}{l}\text { German Society of Perinatal Medicine (Deutsche } \\
\text { Gesellschaft für Perinatale Medizin e.V. [DGPM]) }\end{array}$ \\
\hline
\end{tabular}

\section{Abbreviations}

AED

absent end-diastolic

AEDF absent end-diastolic flow

ARED absent or reversed end-diastolic

ASA acetylsalicylic acid

CPR cerebroplacental ratio

CTG cardiotocography

GW week of gestation

hCG human choriogonadotropin

IUFD intrauterine fetal death

IUGR intrauterine growth restriction

NT nuchal translucency

PAPP-A pregnancy-associated plasma protein A

PI pulsatility index

PIGF placental growth factor

PP13 placental protein 13

RDS respiratory distress syndrome

RED reversed end-diastolic

REDF reversed end-diastolic flow

RR relative risk

SGA small for gestational age

SDP single deepest pocket

s/p status post

STV short-term variation

\section{Guideline Application}

\section{Purpose and Objectives}

This guideline aims to summarize the current state of knowledge on intrauterine growth restriction (IUGR). It focuses on the definition, etiology, diagnosis and management of care and states the best time to deliver the baby.

\section{Targeted areas of patient care}

- Inpatient care

- Outpatient care

\section{Target patient groups}

This guideline is aimed at pregnant patients.

\section{Target user groups/target audience}

This guideline is aimed at the following groups:

- Gynecologists in private practice (non-hospital based)

- Hospital-based gynecologists

- Midwives

\section{Adoption of the guideline and period of validity}

This guideline is valid from May 1, 2017 through to April 30, 2020. Because of the contents of this guideline, the above-mentioned period of validity is only an estimate. If important changes to the available evidence should occur, then amendments to the guideline will be published even before the period of validity has expired, after a careful review of the new evidence in accordance with the methodology published by the AWMF. 


\section{Basic principles}

The methodology used to prepare this guideline is determined by the class assigned to the guideline. The AWMF Guidance Manual (version 1.0) has set out the respective rules and requirements for different classes of guidelines. Guidelines are differentiated into lowest (S1), intermediate (S2) and highest (S3) class. The lowest class is defined as a set of recommendations for action compiled by a non-representative group of experts. In 2004 the S2 class was divided into two subclasses: the systematic evidencebased subclass S2e and the structural consensus-based subclass $\mathrm{S} 2 \mathrm{k}$. The highest $\mathrm{S3}$ class combines both approaches.

This guideline is classified as: $\mathbf{S 2} \mathbf{k}$

\section{Grading of recommendations}

While the classification of the quality of the evidence (strength of evidence) serves as an indication of the robustness of the published data and therefore expresses the extent of certainty/uncertainty about the data, the classification of the level of recommendation reflects the results of weighing up the desirable and adverse consequences of alternative approaches.

The grading of evidence and the grading of recommendations was not envisaged for S2k class guidelines. Individual recommendations are differentiated by syntax, not by symbols. The syntax chosen for the level of recommendation should be described in the background text ( $\triangleright$ Table 2 ).

- Table 2 Grading of recommendations.

\begin{tabular}{|l|l|}
\hline Description of grade of recommendation & Syntax \\
\hline Strong recommendation, highly binding & must/must not \\
\hline Recommendation, moderately binding & should/should not \\
\hline Open recommendation, not binding & may/may not \\
\hline
\end{tabular}

\section{Statements}

Expert statements included in this guideline which are not recommendations for action but are simple statements of fact are referred to as Statements. It is not possible to provide a level of evidence for these statements.

\section{Achieving consensus and level of consensus}

During structured consensus-based decision-making (S2k/S3 level), authorized participants present at a session vote on draft Statements and Recommendations. Discussions during sessions may lead to significant changes in the wording of Statements and Recommendations. The extent of agreement, which depends on the number of participants, is determined at the end of the session ( $\triangleright$ Table 3 ).

\begin{tabular}{|c|c|c|}
\hline Symbol & Level of consensus & Extent of agreement in percent \\
\hline+++ & Strong consensus & $>95 \%$ of participants agree \\
\hline++ & Consensus & $>75-95 \%$ of participants agree \\
\hline+ & Majority agreement & $>50-75 \%$ of participants agree \\
\hline - & No consensus & $<50 \%$ of participants agree \\
\hline
\end{tabular}

\section{Expert consensus}

As the name implies, this refers to consensus decisions taken with regard to specific Recommendations/Statements without a previous systematic search of the literature (S2k) or when evidence is lacking (S2e/S3). The term "Expert Consensus" (EC) used here is synonymous with terms such as "Good Clinical Practice" (GCP) and "Clinical Consensus Point" (CCP) used in other guidelines. The level of recommendation is graded as previously described in the Chapter Grading of recommendations but only semantically ("must"|“must not" or "should"|"should not" or "may"|"may not") and without the use of symbols. 


\section{Guideline}

\section{$1 \quad$ Definition}

\begin{tabular}{l}
\multicolumn{1}{|c|}{ Consensus-based Statement 1.S1 } \\
\hline \multicolumn{1}{|c|}{ Expert consensus } \\
\hline SGA = estimated fetal weight or birth weight $<10$ th percentile \\
IUGR = estimated fetal weight $<10$ th percentile and/or \\
non-percentile appropriate fetal growth during pregnancy and \\
pathological Doppler of umbilical artery or \\
pathological Doppler of uterine artery or \\
oligohydramnios \\
References: $[1-3]$
\end{tabular}

\begin{tabular}{l}
\hline \multicolumn{2}{|c|}{ Consensus-based Statement 1.52} \\
\hline \multicolumn{1}{|c|}{ Expert consensus } \\
\hline Estimated fetal weight or birth weight $<3$ rd percentile is associated with \\
higher levels of morbidity and mortality. \\
References: [4]
\end{tabular}

\section{$2 \quad$ Epidemiology and Etiology}

\begin{tabular}{l}
\hline \multicolumn{1}{|c|}{ Consensus-based Recommendation 2.E1 } \\
\hline \multicolumn{1}{|c|}{ Expert consensus } \\
\hline $\begin{array}{l}\text { Based on their full medical history, all pregnant women must be evaluated } \\
\text { for potential risk factors which could predispose to IUGR. Further diagnostic } \\
\text { investigations must be offered or carried out if risk factors are present. }\end{array}$ \\
References: [5-7]
\end{tabular}

IUGR is a condition which affects approximately $5-10 \%$ of all pregnancies $[5,6]$. The etiology of IUGR is roughly divided into maternal, placental and fetal causes ( $\bullet$ Table 4$)$ [7]. Although the underlying pathophysiological mechanisms may be very different, they often (but not always) lead to the same endpoint: suboptimal uteroplacental perfusion and fetal nutrition. IUGR is therefore associated with high levels of morbidity and mortality.

- Table 4 Risk factors for developing intrauterine growth restriction. Common risk factors are highlighted in bold.

Maternal causes

Uteroplacental causes
Alcohol abuse [8]

Hypertensive disease of pregnancy (pre-eclampsia, gestational hypertension) [9]

Drug/nicotine abuse $[10,11]$

Embryotoxic or fetotoxic medication [12]

Maternal age ( $\geq 35 />40$ years) [13]

Maternal weight (high or very low BMI) [14]

Low socio-economic status $[15,16]$

Nulliparity [17]

$\mathrm{s} / \mathrm{p}$ hypertensive disorder in a previous pregnancy

s/p IUFD [9]

s/p SGA/IUGR [9]

Preexisting maternal diseases, which can lead to reduced uteroplacental perfusion or reduced oxygenation of maternal blood, e.g.: Chronic respiratory disease

Chronic hypertension [18]

Chronic renal disease [19]

Diabetes mellitus with vascular disease [20]

Heart disease, especially cyanotic heart disease [21]

Severe anemia

Systemic lupus erythematosus and antiphospholipid syndrome [22]

Placental abruption [23]

Velamentous cord insertion

Placental infarction [24]

Disorders of placentation with inadequate trophoblast invasion and increased maternal risk of pre-eclampsia [25]

Placental tumors

Chromosomal abnormalities and syndromic disease[26,27]

Intrauterine infections (particularly cytomegaly, toxoplasmosis, rubella, varicella zoster virus)

Multiple pregnancy [28] 


\section{Diagnostics to Detect Possible IUGR}

In addition to taking the patient's history, a clinical examination and various diagnostic procedures must be carried out to rule out or confirm IUGR. This is an important part of antenatal care as the majority of IUGR are not detected prenatally [29] and undetected IUGR is associated with an 8-fold higher risk of intrauterine fetal death [30].

\subsection{Clinical examination}

\section{Consensus-based Recommendation 3.E2}

\section{Expert consensus}

Level of consensus +++

Clinical examinations are of only limited value when screening for SGA/ IUGR. Ultrasound biometry must be carried out for further medical evaluation if there is a suspicion of anomalies.

References: [31]

\subsection{Sonography}

\subsubsection{Biometry in early pregnancy (crown-rump length)}

\section{\begin{tabular}{|c|c|}
\hline \multicolumn{2}{|c|}{ Consensus-based Recommendation 3.E3 } \\
\hline Expert consensus & Level of consensus +++ \\
\hline
\end{tabular}}

Fetal gestational age (based on maternal medical history) must be verified through measurement of the crown-rump length in early pregnancy and corrected if the discrepancy is 7 days or more.

References: [32-36]

\subsubsection{Fetometry}

Consensus-based Recommendation 3.E4

Expert consensus
Level of consensus +++

Further diagnostic investigations must be carried out if the estimated fetal weight is less than the 10 th percentile.

In addition to estimated fetal weight, fetal abdominal circumference is the most important indicator of IUGR. Fetal head-to-abdomen discrepancy can also be an indication of IUGR. Assessment of estimated fetal weight should also take maternal and paternal characteristics into account [37-40]. If the estimated fetal weight is below the 10th percentile, further diagnostic investigations must be carried out (including precise sonographic diagnostics, Doppler sonography).

\subsubsection{Amniotic fluid}

\section{Consensus-based Recommendation 3.E5}

\section{Expert consensus}

Level of consensus +++

Assessment of amniotic fluid volume should be carried out when investigating for possible SGA/IUGR.

References: [41-43]

\subsubsection{Precise sonographic diagnostics (additional procedures for the differential diagnosis of different organs)}

\begin{tabular}{|l|c|}
\hline \multicolumn{2}{|c|}{ Consensus-based Recommendation $3 . E 6$} \\
\hline \multicolumn{1}{|c|}{ Expert consensus } & Level of consensus +++ \\
\hline $\begin{array}{l}\text { Precise sonographic diagnostics should be carried out as part of the inves- } \\
\text { tigation into possible SGA/IUGR. }\end{array}$ \\
\hline References: $[24,26,27,44-47]$
\end{tabular}

\subsection{Doppler sonography}

\begin{tabular}{|c|c|}
\hline \multicolumn{2}{|c|}{ Consensus-based Recommendation 3.E7 } \\
\hline Expert consensus & Level of consensus +++ \\
\hline \multicolumn{2}{|c|}{ Doppler sonography must be carried out to investigate for possible IUGR. } \\
\hline References: [48] & \\
\hline
\end{tabular}

\subsection{Cardiotocography (CTG)}

Cardiotocography (CTG) is known to have a high false-positive rate for the prediction of poor outcomes and is more likely to detect acute hypoxic events than chronic conditions [49]. Its value for detecting possible IUGR is therefore only limited; nevertheless, according to the German Maternity Guidelines, CTG should be carried out as part of antenatal care if there is a suspicion of placental insufficiency [48].

\section{Differential diagnosis of a SGA/IUGR fetus \\ 4.1 Chromosomal anomalies}

\section{Consensus-based Recommendation 4.E8}

Expert consensus Level of consensus +++

Karyotyping should be considered when an SGA/IUGR fetus is identified, particularly if there is a suspicion of anomalies.

References: [26, 27, 44, 45, 50-52]

\section{$4.2 \quad$ Infections}

\begin{tabular}{|l|}
\hline \multicolumn{1}{|c|}{ Consensus-based Recommendation 4.E9 } \\
\hline \multicolumn{1}{|c|}{ Expert consensus } \\
\hline Examination for possible infections should be considered when an SGA/ \\
IUGR fetus is identified. \\
\hline References: [53]
\end{tabular}

\section{$5 \quad$ Management of IUGR}

There is still very little evidence about the best antenatal method to monitor a fetus with IUGR [54]. No single monitoring method provides a valid prediction for the outcome of IUGR, which is why a combination of different procedures to monitor growth-retarded fetuses is recommended. 


\section{$5.1 \quad$ Diagnostic monitoring}

\subsubsection{Clinical examination}

Consensus-based Recommendation 5.E10

Expert consensus

Level of consensus +++

Monitoring should be carried out to detect early signs of pre-eclampsia when IUGR is caused by uteroplacental insufficiency.

\subsubsection{Sonography (fetometry)}

\begin{tabular}{|c|c|}
\hline \multicolumn{2}{|c|}{ Consensus-based Recommendation 5.E11 } \\
\hline Expert consensus & Level of consensus +++ \\
\hline \multicolumn{2}{|c|}{$\begin{array}{l}\text { Serial sonographic monitoring of fetal growth must be carried out when } \\
\text { IUGR has been identified or there is a suspicion of IUGR. }\end{array}$} \\
\hline References: [55] & \\
\hline
\end{tabular}

\section{\begin{tabular}{|l|l|}
\hline \multicolumn{2}{|c|}{ Consensus-based Recommendation 5. E12 } \\
\hline \multicolumn{1}{|c|}{ Expert consensus } & Level of consensus +++ \\
\hline $\begin{array}{l}\text { The interval between individual sonography scans to monitor fetal growth } \\
\text { should be at least two weeks. }\end{array}$
\end{tabular}}

\subsubsection{Sonography (amniotic fluid)}

\begin{tabular}{|c|c|}
\hline \multicolumn{2}{|c|}{ Consensus-based Recommendation 5. E13 } \\
\hline Expert consensus & Level of consensus +++ \\
\hline
\end{tabular}

Sonographic assessment of amniotic fluid volume must only be interpreted in the context of and together with other monitoring methods.

\section{Consensus-based Recommendation 5.E14}

Expert consensus

Level of consensus +++

The SDP (single deepest pocket) method should be used to assess amniotic fluid volume.

References: [56-58]

\subsubsection{Doppler sonography (umbilical artery)}

\begin{tabular}{|c|c|}
\hline \multicolumn{2}{|c|}{ Consensus-based Recommendation 5.E15 } \\
\hline Expert consensus & Level of consensus +++ \\
\hline
\end{tabular}

The management of IUGR must include Doppler sonography of the umbilical artery as it can reduce perinatal mortality in high-risk pregnancies.

References: $[59,60]$

\section{Consensus-based Statement 5.S3}

Expert consensus

Level of consensus +++

Normal results for Doppler sonography of the umbilical artery in early IUGR is associated with a low risk of poor perinatal outcome.

References: $[4,61]$

\section{Consensus-based Statement 5.54}

Expert consensus

Level of consensus +++

Diastolic zero flow (AED flow) and reverse diastolic blood flow (RED flow) particularly in the umbilical artery are commonly associated with poor perinatal outcome when IUGR is present.

References: [62-67]

\begin{tabular}{|l|}
\hline \multicolumn{1}{|c|}{ Consensus-based Recommendation 5. E16 } \\
\hline \multicolumn{1}{|c|}{ Expert consensus } \\
\hline The intervals between control Doppler scans should always depend on the \\
severity of IUGR and on previous Doppler findings.
\end{tabular}

\section{Consensus-based Statement 5.S5}

\section{Expert consensus Level of consensus +++}

When Doppler results for the umbilical artery are normal, repeat control scans every two weeks appear to be sufficient to monitor early IUGR. More frequent control scans may be needed in cases of severe IUGR.

References: [68,69]

\section{Consensus-based Recommendation 5.E17}

Expert consensus Level of consensus +++

It is not clear how long the intervals between control Doppler scans should be if the findings of the umbilical artery are pathological. If pulsatility is increased ( $\mathrm{PI}>95$ th percentile) controls should be carried out at least once a week; in cases of ARED flow, monitoring must be carried out at even more frequent intervals.

\section{Consensus-based Recommendation 5.E18}

\section{Expert consensus} Level of consensus +++

If Doppler sonography of the umbilical artery shows abnormalities, additional Doppler scans of other vessels (middle cerebral artery, ductus venosus) should be carried out. 


\subsubsection{Doppler sonography (middle cerebral artery)}

\section{Consensus-based Recommendation 5.E19}

Expert consensus

Level of consensus +++

Doppler sonography of the middle cerebral artery should be done in addition to sonography of the umbilical artery when IUGR is detected.

References: [70-72]

\section{Consensus-based Statement 5.S6}

\section{Expert consensus}

Level of consensus ++

Pathological Doppler findings for the middle cerebral artery ( $\mathrm{Pl}<5$ th percentile) in late IUGR at term increases the risk of cesarean section and poor perinatal outcome.

References: [73-75]

\subsubsection{Doppler sonography (cerebroplacental ratio, CPR)}

\begin{tabular}{|c|c|}
\hline \multicolumn{2}{|c|}{ Consensus-based Statement 5.S7 } \\
\hline Expert consensus & Level of consensus +++ \\
\hline
\end{tabular}

The cerebroplacental ratio (CPR), which is calculated by dividing the PI of the middle cerebral artery by the PI of the umbilical artery, can be useful to monitor IUGR as a low CPR is a predictor for poor perinatal outcome.

References: $[70,71,76-80]$

\subsubsection{Doppler sonography (ductus venosus)}

\begin{tabular}{l}
\multicolumn{1}{c|}{ Consensus-based Statement $\mathbf{5 . 5 8}$} \\
\hline \multicolumn{1}{|c|}{ Expert consensus } \\
\hline $\begin{array}{l}\text { An absent or reversed a-wave on Doppler sonography of the ductus veno- } \\
\text { sus is an indication of imminent or manifest acidemia and the risk of fetal } \\
\text { death. }\end{array}$ \\
References: $[81-83]$
\end{tabular}

\section{Consensus-based Recommendation 5.E20}

\section{\begin{tabular}{l|l} 
Expert consensus & Level of consensus +++
\end{tabular}}

Monitoring of early IUGR must include Doppler sonography of the ductus venosus.

References: $[72,84,85]$

\subsubsection{Doppler sonography (other vessels)}

The predictive value of Doppler sonography of the uterine arteries in the last third of pregnancy is unclear as no evidence-based data are available. Doppler sonography of other arterial (e.g. the fetal aorta) and venous (e.g. umbilical vein, inferior vena cava) vessels is currently only recommended if it is carried out as part of a study, as the evidence for its usefulness is still insufficient.

\subsubsection{Cardiotocography (CTG)}

\begin{tabular}{l} 
Consensus-based Recommendation 5.E21 \\
\hline \multicolumn{1}{|c|}{ Expert consensus } \\
\hline $\begin{array}{l}\text { Cardiotocography (CTG) must not be the only procedure used to monitor } \\
\text { IUGR. }\end{array}$ \\
References: $[86,87]$
\end{tabular}

\subsubsection{Computerized CTG (Dawes-Redman CTG analysis)}

\begin{tabular}{|l|}
\hline \multicolumn{1}{|c|}{ Consensus-based Statement 5.S9 } \\
\hline \multicolumn{1}{|c|}{ Expert consensus } \\
\hline $\begin{array}{l}\text { Analysis of short-term fetal heart variation based on computerized CTG } \\
\text { (Dawes-Redman CTG analysis) may be useful for monitoring IUGR. }\end{array}$ \\
\hline References: $[84,88-100]$
\end{tabular}

\subsubsection{Biophysical profile}

\begin{tabular}{|c|c|}
\hline \multicolumn{2}{|c|}{ Consensus-based Recommendation 5.E22 } \\
\hline Expert consensus & Level of consensus +++ \\
\hline \multicolumn{2}{|c|}{ The biophysical profile (scoring) should not be used to monitor IUGR. } \\
\hline References: $[84,101-103]$ & \\
\hline
\end{tabular}

\subsection{Antenatal corticosteroids (RDS prophylaxis)}

\begin{tabular}{|c|c|}
\hline \multicolumn{2}{|c|}{ Consensus-based Recommendation 5.E23 } \\
\hline Expert consensus & Level of consensus +++ \\
\hline \multicolumn{2}{|c|}{$\begin{array}{l}\text { Antenatal corticosteroids should be administered once between GW } 24+0 \\
\text { and GW } 34+0 \text { if it is expected that the infant will be delivered within the } \\
\text { next } 7 \text { days. }\end{array}$} \\
\hline References: [104] & \\
\hline
\end{tabular}

\subsection{Magnesium sulfate for fetal neuroprotection}

\section{Consensus-based Recommendation 5.E24}

Expert consensus

Level of consensus +++

Magnesium sulfate for fetal neuroprotection may be administered if preterm birth $(\mathrm{GW}<32+0)$ is expected, as there are indications that it has a neuroprotective effect.

References: [105-115] 


\subsection{Delivery \\ 5.4.1 Place of delivery}

\section{Consensus-based Recommendation 5.E25}

Expert consensus

Level of consensus +++

If IUGR is present, the infant must be delivered in a perinatal center with a neonatal intensive care unit and an experienced team on hand to provide immediate and continuous care.

References: [116,117]

\subsubsection{Time of delivery}

\begin{tabular}{|c|c|}
\hline \multicolumn{2}{|c|}{ Consensus-based Recommendation 5.E26 } \\
\hline Expert consensus & Level of consensus +++ \\
\hline
\end{tabular}

Early IUGR and late IUGR must be assessed differently. Increasing deterioration in a fetus with early IUGR is reflected in abnormalities of venous Doppler parameters, while increasing deterioration in a fetus with late IUGR is primarily visible in abnormal cerebral Doppler findings.

References: [62]

\section{Consensus-based Recommendation 5.E27}

\section{Expert consensus $\quad$ Level of consensus +++}

When planning the time of delivery, the risks associated with preterm birth must be weighed up against the risks of remaining in the womb.

References: [118]

\section{Consensus-based Statement 5.S10}

Expert consensus

Level of consensus +++

Age of gestation is a significant factor affecting survival without morbidity.

References: $[3,72,119,120]$

\section{Consensus-based Recommendation 5.E28}

\section{Expert consensus $\quad$ Level of consensus +++}

If CTG pathologies such as recurrent decelerations resistant to treatment occur, delivery of the infant must be considered at all times.

References: [100]

\section{Consensus-based Recommendation 5.E29}

\section{Expert consensus}

Delivery of the infant must be considered if short-term variation (STV) $<2.6$ ms occurs between GW $26+0$ and GW $28+6$ or a STV $<3$ ms occurs between GW $29+0$ and GW $32+0$.

References: [100]

\section{Consensus-based Recommendation 5.E30}

\section{Expert consensus}

Level of consensus ++

If Doppler sonography of the ductus venosus shows increased pulsatility (PI $>95$ th percentile), delivery of the infant should be considered, depending on gestational age.

References: $[100,118,121,122]$

\section{Consensus-based Recommendation 5.E31}

\section{Expert consensus Level of consensus +++}

If Doppler sonography of the ductus venosus shows an absence of a-wave (AEDF) or reverse flow (REDF) of a-wave, delivery of the infant must be considered.

References: $[100,118,121,122]$

\section{Consensus-based Recommendation 5.E32}

Expert consensus

Level of consensus +++

If Doppler sonography of the umbilical artery reveals reversed end-diastolic flow (REDF), the infant should be delivered by GW $32+0$ at the latest.

\section{Consensus-based Recommendation 5.E33}

Expert consensus $\quad$ Level of consensus +++

If Doppler sonography of the umbilical artery reveals absent end-diastolic flow (AEDF), the infant should be delivered by GW $34+0$ at the latest.

\section{Consensus-based Recommendation 5.E34}

\section{Expert consensus}

Level of consensus +++

If Doppler sonography of the umbilical artery reveals increased pulsatility ( $\mathrm{PI}>95$ th percentile), the aim should be to deliver the infant from GW $37+0$.

References: [123]

\section{Consensus-based Recommendation 5.E35}

\section{Expert consensus $\quad$ Level of consensus ++}

If Doppler sonography of the middle cerebral artery reveals decreased pulsatility ( $\mathrm{PI}<5$ th percentile), delivery of the infant by GW $37+0$ at the latest should be considered.

\section{Consensus-based Recommendation 5.E36}

Expert consensus $\quad$ Level of consensus +++

If the CPR (cerebroplacental ratio) is low, the aim from GW $37+0$ should be to deliver the infant.

References: [61, 77-80] 
Consensus-based Recommendation 5.E37

Expert consensus

Level of consensus +++

In the case of an isolated SGA (normal Doppler results, no additional risks), delivery may be considered from GW $38+0$.

References: [124-126]

Consensus-based Recommendation 5.E38

Expert consensus

Level of consensus +++

In the case of an isolated SGA (normal Doppler results, no additional risks), the due date must not be exceeded.

\subsubsection{Type of delivery}

Consensus-based Recommendation 5.E39

Expert consensus Level of consensus +++

Not every pregnant woman with IUGR must be delivered by C-section.

Consensus-based Recommendation 5.E40

Expert consensus

Level of consensus +++

In the case of IUGR with normal Doppler results or increased pulsatility in the umbilical artery ( $>95$ th percentile), labor may be induced with the goal of vaginal delivery but not if ARED flow is present. However the higher risk of complications must be taken into account and continuous intrapartum monitoring is required.

References: [127-133]

\subsubsection{Additional recommendations}

Outpatient or inpatient monitoring and care

\section{Consensus-based Recommendation 5.E41}

Expert consensus

Level of consensus +++

The decision for either outpatient or inpatient monitoring and care of the pregnant woman with IUGR must be taken on an individual basis.

\section{Bed rest}

There is very little evidence-based data on hospitalization with bed rest when there is a suspicion of fetal growth restriction, and the data have not shown any benefit [134].

\section{Diet}

Changes in diet, dietary measures or additional intake of food supplements (e.g. calcium [135]) have not shown any benefit [136] and are therefore not recommended.

\section{Cessation of nicotine use}

\section{Consensus-based Recommendation 5.E42}

Expert consensus Level of consensus +++

Cessation of nicotine use must be recommended to all pregnant women.

References: [137]

\section{Progesterone}

Progesterone has shown no benefit in reducing IUGR [138] and should therefore not be administered for that purpose.

\section{Maternal oxygen administration}

The studies on the benefits of maternal oxygen administration are insufficient and some have methodological flaws. These studies were evaluated in an older Cochrane analysis which drew the conclusion that the existing evidence is insufficient to assess the benefits and risk of maternal oxygen administration [139]; maternal oxygen should therefore not be administered.

\section{Other interventions}

Numerous interventions which aim to improve blood flow to the placenta have been studied [140]. But neither the increase in plasma volume [141] nor the administration of low-dose ASA [142] or sildenafil $[143,144]$ showed any benefit, and they are therefore not recommended.

Antihypertensive therapy of pregnant women with hypertensive disease does not improve fetal growth $[145,146]$ and should not be recommended and neither should the administration of NO donors or vasodilator substances as they have not been sufficiently investigated yet [147].

\section{$6 \quad$ Information and counseling}

The pregnant woman or parents-to-be should receive detailed information and extensive counseling sessions about IUGR as a complication of pregnancy and the individual course and consequences of IUGR. The mother/parents-to-be should also be told that the infant could be constitutionally small, which does not inevitably lead to increased perinatal morbidity. These talks should be given by an interdisciplinary team which includes a specialist for prenatal medicine/obstetrician and neonatologist. Depending on the fetal clinical picture, additional pediatric specialists or specialists for human genetics should also be consulted. In addition to information about the possible causes, information should also be provided about the short-term and long-term consequences, the risk of recurrence and, depending on the case, the possible diagnostic investigations.

The individual medical, psychological and social questions of the pregnant woman or the parents-to-be about the diagnosis must then be discussed during a comprehensive medical consultation. All necessary decisions should be taken as part of a joint decision-making process. The most important results of the information and counseling sessions should be documented transparently (see also the S2k-guideline "Preterm infants born at the limits of viability", currently only available in German: "Frühgeborene an der Grenze der Lebensfähigkeit” (196)). 
Additional psychological or pastoral care, ideally initiated before the birth, can be an important aspect for parents-to-be [148].

\section{$7 \quad$ Prophylaxis}

Particularly after a previous IUGR pregnancy, the aim must be to prevent a recurrence of IUGR. Numerous approaches have been used in the past, but only a few of them offer an evidence-based benefit.

Acetylsalicylic acid (ASA)

\begin{tabular}{l} 
Consensus-based Recommendation 7.E43 \\
\hline \multicolumn{1}{|c|}{ Expert consensus } \\
\hline If there is a risk of uteroplacental malperfusion and a risk of IUGR, prophy- \\
lactic intake of low-dose ASA should be started at $\leq 16 \mathrm{GW}$. \\
References: [149-151]
\end{tabular}

\section{Antihypertensive therapy}

Antihypertensive therapy of mild to moderate hypertension during pregnancy does not appear to increase the risk of SGA fetus (RR: 1.02; 95\% Cl: 0.89-1.16) [145]. However, the use of betablockers in antihypertensive therapy is associated with growth restriction (RR: 1.36, 95\% Cl: 1.02-1.82) [152] and should therefore be avoided if possible.

\section{Bed rest}

There is no evidence that prophylactic (outpatient or inpatient) bed rest can prevent IUGR [134].

\section{Diet}

\begin{tabular}{|l|}
\hline \multicolumn{1}{|c|}{ Consensus-based Recommendation 7.E44 } \\
\hline \multicolumn{1}{|c|}{ Expert consensus } \\
\hline $\begin{array}{l}\text { Special forms of nutrition or food supplements have not been shown to of- } \\
\text { fer an evidence-based benefit and should therefore not be recommended } \\
\text { as prophylaxis against IUGR. }\end{array}$ \\
\hline References: $[135,153-158]$
\end{tabular}

Heparin

\begin{tabular}{|c|c|}
\hline \multicolumn{2}{|c|}{ Consensus-based Statement 7.S11 } \\
\hline Expert consensus & Level of consensus +++ \\
\hline \multicolumn{2}{|c|}{$\begin{array}{l}\text { The administration of low-molecular-weight heparin appears to be a } \\
\text { promising prophylactic approach in IUGR. Nevertheless, the currently } \\
\text { available evidence is not sufficient for it to be recommended, particularly as } \\
\text { there is insufficient evidence concerning possible severe side-effects. }\end{array}$} \\
\hline s: [159-161] & \\
\hline
\end{tabular}

Nicotine

\begin{tabular}{|l|}
\hline \multicolumn{1}{|c|}{ Consensus-based Recommendation 7.E45 } \\
\hline \multicolumn{1}{|c|}{ Expert consensus Level of consensus +++ } \\
\hline $\begin{array}{l}\text { All pregnant women who smoke must be informed that abstaining from } \\
\text { nicotine can reduce the risk of IUGR. }\end{array}$ \\
\hline References: $[162,163]$ \\
\hline
\end{tabular}

\section{$8 \quad$ Screening}

Antenatal detection of IUGR is vitally important, as early detection significantly influences both the course of pregnancy and the neonatal outcome $[29,164,165]$.

\section{Medical history}

A careful investigation of the patient's medical history, particularly with regard to potential risk factors for IUGR (see Chapter 2. Epidemiology and Etiology), is essential as close monitoring can be initiated if there is an increased risk of IUGR [166].

\section{Clinical examination}

\section{(Cf. Chapter 3.1. Clinical examination)}

\section{Sonography}

The basic prerequisite for effective screening is accurate data collection (Chapter 3.2.1. Crown-rump length).

In addition, it is suggested that, similar to pre-eclampsia screening in the 1st trimester of pregnancy, an attempt could be made to screen for SGA/IUGR using a combination of different markers (maternal medical history, Doppler sonography of the uterine arteries, middle arterial pressure, NT and the maternal serum markers PAPP-A, free $\beta$-hCG, PIGF, PP13, and ADAM 12). General screening is not currently recommended yet.

\section{Doppler sonography}

\begin{tabular}{|c|c|}
\hline \multicolumn{2}{|c|}{ Consensus-based recommendation 8.E46 } \\
\hline Expert consensus & Level of consensus +++ \\
\hline \multicolumn{2}{|c|}{$\begin{array}{l}\text { Abnormal Doppler results for the uterine arteries in the form of increased } \\
\text { pulsatility (PI > 95th percentile) should be a signal to start regular sono- } \\
\text { graphic monitoring of fetal growth and Doppler sonography of the umbil- } \\
\text { ical artery. }\end{array}$} \\
\hline References: $[167,168]$ & \\
\hline
\end{tabular}


( Figs. 1 and 2)

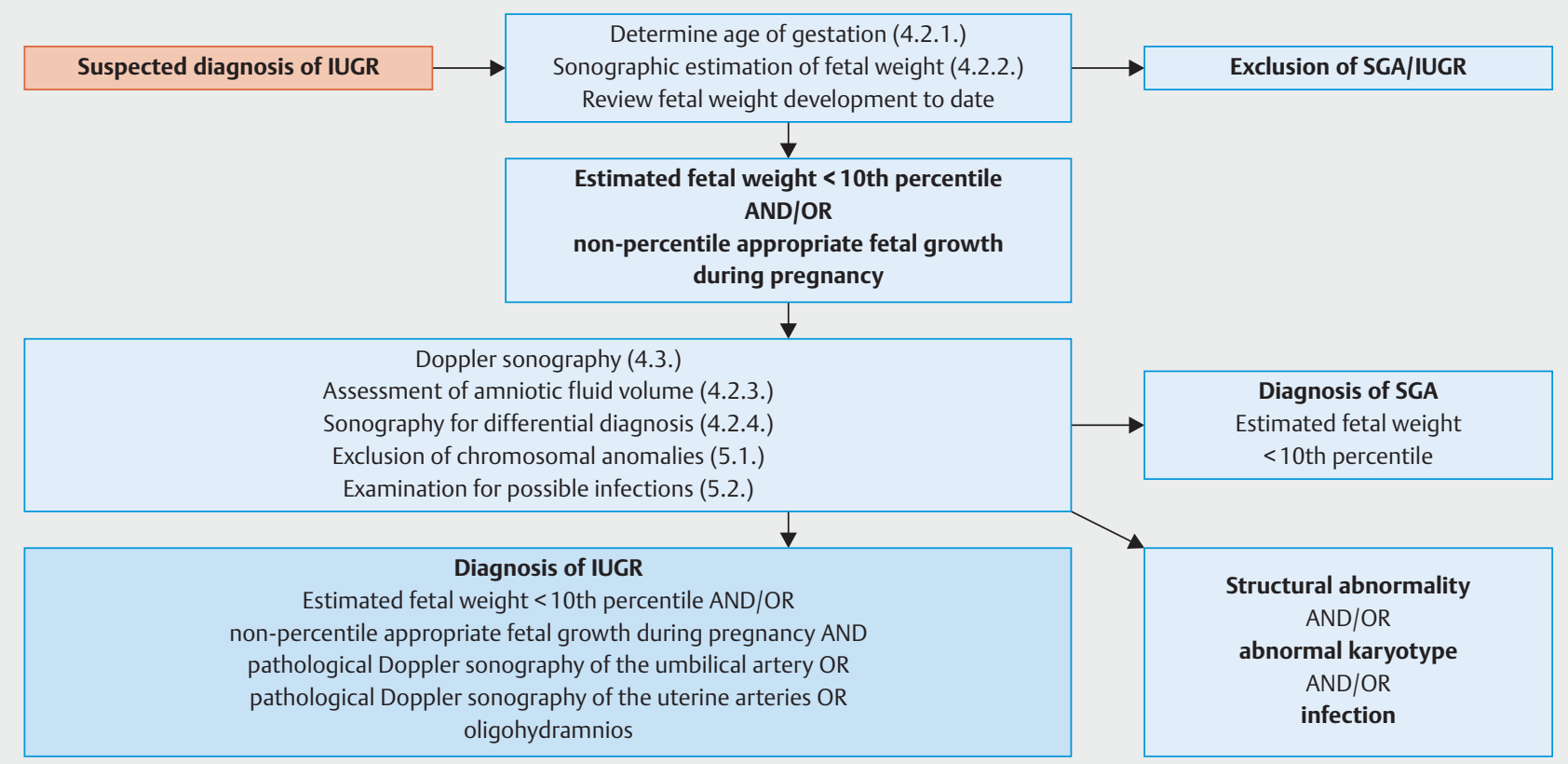

- Fig. 1 Algorithm for the diagnosis of IUGR.

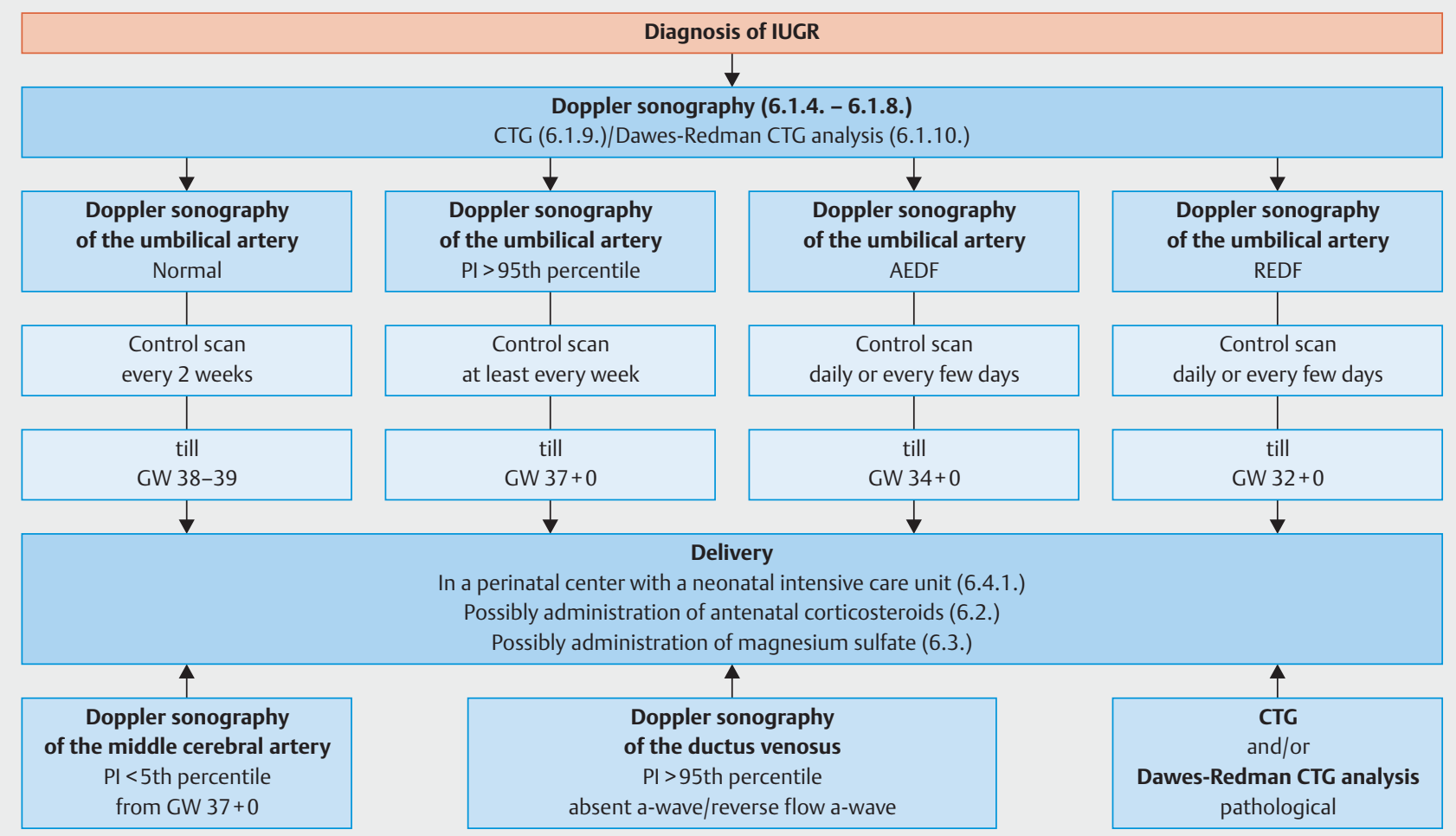

- Fig. 2 Algorithm for the management of IUGR. 
[1] Unterscheider J, Daly S, Geary MP et al. Definition and management of fetal growth restriction: a survey of contemporary attitudes. Eur J Obstet Gynecol Reprod Biol 2014; 174: 41-45

[2] Alberry M, Soothill P. Management of fetal growth restriction. Arch Dis Child Fetal Neonatal Ed 2007; 92: F62-F67

[3] Lees C, Marlow N, Arabin B et al. Perinatal morbidity and mortality in early-onset fetal growth restriction: cohort outcomes of the trial of randomized umbilical and fetal flow in Europe (TRUFFLE). Ultrasound Obstet Gynecol 2013; 42: 400-408

[4] Unterscheider J, Daly S, Geary MP et al. Optimizing the definition of intrauterine growth restriction: the multicenter prospective PORTO Study. Am J Obstet Gynecol 2013; 208: 290.e1-290.e6

[5] Albu AR, Anca AF, Horhoianu VV et al. Predictive factors for intrauterine growth restriction. J Med Life 2014; 7: 165-171

[6] Parker SE, Werler MM. Epidemiology of ischemic placental disease: a focus on preterm gestations. Semin Perinatol 2014; 38: 133-138

[7] Berlit S, Nickol J, Weiss $C$ et al. Zervixdilatation und Kürettage während eines primären Kaiserschnitts - eine retrospektive Analyse. Z Geburtshilfe Neonatol 2013. doi:217-V220_211

[8] Jaddoe VW, Bakker R, Hofman A et al. Moderate alcohol consumption during pregnancy and the risk of low birth weight and preterm birth. The generation R study. Ann Epidemiol 2007; 17: 834-840

[9] Ananth CV, Peltier MR, Chavez MR et al. Recurrence of ischemic placental disease. Obstet Gynecol 2007; 110: 128-133

[10] Gouin K, Murphy K, Shah PS et al. Effects of cocaine use during pregnancy on low birthweight and preterm birth: systematic review and metaanalyses. Am J Obstet Gynecol 2011; 204: 340.e1-340.e12

[11] Kramer MS, Platt R, Yang $\mathrm{H}$ et al. Are all growth-restricted newborns created equal(ly)? Pediatrics 1999; 103: 599-602

[12] Maulik D. Fetal growth restriction: the etiology. Clin Obstet Gynecol 2006; 49: 228-235

[13] Odibo AO, Nelson D, Stamilio DM et al. Advanced maternal age is an independent risk factor for intrauterine growth restriction. Am J Perinatol 2006; 23: 325-328

[14] Gardosi ], Francis A. Adverse pregnancy outcome and association with small for gestational age birthweight by customized and populationbased percentiles. Am J Obstet Gynecol 2009; 201: 28.e1-28.e8

[15] Kleijer ME, Dekker GA, Heard AR. Risk factors for intrauterine growth restriction in a socio-economically disadvantaged region. J Matern Fetal Neonatal Med 2005; 18: 23-30

[16] Blumenshine P, Egerter S, Barclay C] et al. Socioeconomic disparities in adverse birth outcomes: a systematic review. Am J Prev Med 2010; 39: 263-272

[17] Shah PS; Knowledge Synthesis Group on Determinants of LBW/PT births. Parity and low birth weight and preterm birth: a systematic review and meta-analyses. Acta Obstet Gynecol Scand 2010; 89: 862-875

[18] Allen VM, Joseph K, Murphy KE et al. The effect of hypertensive disorders in pregnancy on small for gestational age and stillbirth: a population based study. BMC Pregnancy Childbirth 2004; 4: 17

[19] Fink JC, Schwartz SM, Benedetti TJ et al. Increased risk of adverse maternal and infant outcomes among women with renal disease. Paediatr Perinat Epidemiol 1998; 12: 277-287

[20] Howarth C, Gazis A, James D. Associations of Type 1 diabetes mellitus, maternal vascular disease and complications of pregnancy. Diabet Med 2007; 24: 1229-1234

[21] Drenthen W, Pieper PG, Roos-Hesselink JW et al. Outcome of pregnancy in women with congenital heart disease: a literature review. J Am Coll Cardiol 2007; 49: 2303-2311
[22] Yasuda M, Takakuwa K, Tokunaga A et al. Prospective studies of the association between anticardiolipin antibody and outcome of pregnancy. Obstet Gynecol 1995; 86: 555-559

[23] Costa SL, Proctor L, Dodd JM et al. Screening for placental insufficiency in high-risk pregnancies: is earlier better? Placenta 2008; 29: 1034-1040

[24] Laurini R, Laurin J, Marsal K. Placental histology and fetal blood flow in intrauterine growth retardation. Acta Obstet Gynecol Scand 1994; 73: 529-534

[25] Salafia CM, Minior VK, Pezzullo JC et al. Intrauterine growth restriction in infants of less than thirty-two weeks' gestation: associated placental pathologic features. Am J Obstet Gynecology 1995; 173: 1049-1057

[26] Eydoux P, Choiset A, Le Porrier N et al. Chromosomal prenatal diagnosis: study of 936 cases of intrauterine abnormalities after ultrasound assessment. Prenat Diagn 1989; 9: 255-269

[27] Khoury M], Erickson JD, Cordero JF et al. Congenital malformations and intrauterine growth retardation: a population study. Pediatrics 1988; 82: 83-90

[28] Powers WF, Kiely JL. The risks confronting twins: a national perspective. Am J Obstet Gynecol 1994; 170: 456-461

[29] Chauhan SP, Beydoun H, Chang E et al. Prenatal detection of fetal growth restriction in newborns classified as small for gestational age: correlates and risk of neonatal morbidity. Am J Perinatol 2014; 31: 187 194

[30] Gardosi ], Madurasinghe V, Williams M et al. Maternal and fetal risk factors for stillbirth: population based study. BMJ 2013; 346: f108

[31] Goetzinger KR, Tuuli MG, Odibo AO et al. Screening for fetal growth disorders by clinical exam in the era of obesity. J Perinatol 2013; 33: 352357

[32] Mongelli M, Wilcox M, Gardosi J. Estimating the date of confinement: ultrasonographic biometry versus certain menstrual dates. Am J Obstet Gynecol 1996; 174: 278-281

[33] Whitworth M, Bricker L, Mullan C. Ultrasound for fetal assessment in early pregnancy. Cochrane Database Syst Rev 2015; (7): CD007058

[34] Wisser J, Dirschedl P, Krone S. Estimation of gestational age by transvaginal sonographic measurement of greatest embryonic length in dated human embryos. Ultrasound Obstet Gynecol 1994; 4: 457-462

[35] [Anonym]. Committee opinion no 611: method for estimating due date. Obstet Gynecol 2014; 124: 863-866

[36] [Anonym]. Standards zur Ultraschalluntersuchung in der Frühschwangerschaft. Leitlinie der Deutschen Gesellschaft für Gynäkologie und Geburtshilfe (S1-Level, AWMF-Register Nr. 015/032, August 2010). Online: http://www.dggg.de/leitlinienstellungnahmen/archivierte-leitlinien/ federfuehrende-leitlinien-der-dggg/?elD=dam_frontend_push\&doclD= 2068; last access: 20.07.2016

[37] Gardosi J, Chang A, Kalyan B et al. Customised antenatal growth charts. Lancet 1992; 339: 283-287

[38] Unterscheider J, Geary MP, Daly S et al. The customized fetal growth potential: a standard for Ireland. Eur J Obstet Gynecol Reprod Biol 2013; 166: $14-17$

[39] Figueras F, Figueras J, Meler E et al. Customised birthweight standards accurately predict perinatal morbidity. Arch Dis Child Fetal Neonatal Ed 2007; 92: F277-F280

[40] Groom KM, Poppe KK, North RA et al. Small-for-gestational-age infants classified by customized or population birthweight centiles: impact of gestational age at delivery. Am J Obstet Gynecol 2007; 197: 239.e1239.e5

[41] Chauhan SP, Magann EF, Dohrety DA et al. Prediction of small for gestational age newborns using ultrasound estimated and actual amniotic fluid volume: published data revisited. Aust N Z J Obstet Gynaecol 2008; 48: $160-164$ 
[42] Owen P, Khan KS, Howie P. Single and serial estimates of amniotic fluid volume and umbilical artery resistance in the prediction of intrauterine growth restriction. Ultrasound Obstet Gynecol 1999; 13: 415-419

[43] Patterson RM, Prihoda T], Pouliot MR. Sonographic amniotic fluid measurement and fetal growth retardation: a reappraisal. Am J Obstet Gynecol 1987; 157: 1406-1410

[44] Niknafs P, Sibbald J. Accuracy of single ultrasound parameters in detection of fetal growth restriction. Am J Perinatol 2001; 18: 325-334

[45] Snijders RJ, Sherrod C, Gosden CM et al. Fetal growth retardation: associated malformations and chromosomal abnormalities. Am J Obstet Gynecol 1993; 168: 547-555

[46] Wallenstein MB, Harper LM, Odibo AO et al. Fetal congenital heart disease and intrauterine growth restriction: a retrospective cohort study. J Matern Fetal Neonatal Med 2012; 25: 662-665

[47] Raynor BD, Richards D. Growth retardation in fetuses with gastroschisis. J Ultrasound Med 1997; 16: 13-16

[48] Kehl S, Schmidt U, Spaich S et al. Where are the limits of accuracy for fetal weight estimation with two-dimensional parameters? Ultrasound Obstet Gynecol 2011; 38: 151

[49] Evertson LR, Gauthier RJ, Schifrin BS et al. Antepartum fetal heart rate testing. I. Evolution of the nonstress test. Am J Obstet Gynecol 1979; 133: 29-33

[50] Bahado-Singh RO, Lynch L, Deren O et al. First-trimester growth restriction and fetal aneuploidy: the effect of type of aneuploidy and gestational age. Am J Obstet Gynecol 1997; 176: 976-980

[51] Anandakumar C, Chew S, Wong YC et al. Early asymmetric IUGR and aneuploidy. J Obstet Gynaecol Res 1996; 22: 365-370

[52] Wilkins-Haug L, Roberts DJ, Morton CC. Confined placental mosaicism and intrauterine growth retardation: a case-control analysis of placentas at delivery. Am J Obstet Gynecol 1995; 172: 44-50

[53] Hendrix N, Berghella V. Non-placental causes of intrauterine growth restriction. Semin Perinatol 2008; 32: 161-165

[54] Grivell RM, Wong L, Bhatia V. Regimens of fetal surveillance for impaired fetal growth. Cochrane Database Syst Rev 2012; 6: CD007113

[55] Mongelli M, Ek S, Tambyrajia R. Screening for fetal growth restriction: a mathematical model of the effect of time interval and ultrasound error. Obstet Gynecol 1998; 92: 908-912

[56] Nabhan AF, Abdelmoula YA. Amniotic fluid index versus single deepest vertical pocket as a screening test for preventing adverse pregnancy outcome. Cochrane Database Syst Rev 2008; (3): CD006593. doi:10.1002/ 14651858.CD006593.pub2

[57] Nabhan AF, Abdelmoula YA. Amniotic fluid index versus single deepest vertical pocket: a meta-analysis of randomized controlled trials. Int J Gynaecol Obstet 2009; 104: 184-188

[58] Kehl S, Schelkle A, Thomas A et al. Single deepest vertical pocket or amniotic fluid index as evaluation test for predicting adverse pregnancy outcome (SAFE trial): a multicenter, open-label, randomized controlled trial. Ultrasound Obstet Gynecol 2016; 47: 674-679

[59] Alfirevic Z, Stampalija T, Gyte GM. Fetal and umbilical Doppler ultrasound in high-risk pregnancies. Cochrane Database Syst Rev 2013; (11): CD007529

[60] Berkley E, Chauhan SP, Abuhamad A; Society for Maternal-Fetal Medicine Publications Committee. Doppler assessment of the fetus with intrauterine growth restriction. Am J Obstet Gynecol 2012; 206: 300-308

[61] O’Dwyer V, Burke G, Unterscheider J et al. Defining the residual risk of adverse perinatal outcome in growth-restricted fetuses with normal umbilical artery blood flow. Am J Obstet Gynecol 2014; 211: 420.e1-420. e5

[62] Baschat AA. Fetal growth restriction - from observation to intervention. J Perinat Med 2010; 38: 239-246
[63] Nicolaides KH, Bilardo CM, Soothill PW et al. Absence of end diastolic frequencies in umbilical artery - a sign of fetal hypoxia and acidosis. Brit Med J 1988; 297: 1026-1027

[64] Kingdom JC, Burrell SJ, Kaufmann P. Pathology and clinical implications of abnormal umbilical artery Doppler waveforms. Ultrasound Obstet Gynecol 1997; 9: 271-286

[65] Brodszki ], Morsing E, Malcus P et al. Early intervention in management of very preterm growth-restricted fetuses: 2-year outcome of infants delivered on fetal indication before 30 gestational weeks. Ultrasound Obstet Gynecol 2009; 34: 288-296

[66] Hartung J, Kalache KD, Heyna C et al. Outcome of 60 neonates who had ARED flow prenatally compared with a matched control group of appropriate-for-gestational age preterm neonates. Ultrasound Obstet Gynecol 2005; 25: 566-572

[67] Vasconcelos RP, Brazil Frota Aragao JR, Costa Carvalho FH et al. Differences in neonatal outcome in fetuses with absent versus reverse end-diastolic flow in umbilical artery Doppler. Fetal Diagn Ther 2010; 28: 160 166

[68] Nienhuis SJ, Vles JS, Gerver WJ et al. Doppler ultrasonography in suspected intrauterine growth retardation: a randomized clinical trial. UItrasound Obstet Gynecol 1997; 9: 6-13

[69] McCowan LM, Harding JE, Roberts $A B$ et al. A pilot randomized controlled trial of two regimens of fetal surveillance for small-for-gestational-age fetuses with normal results of umbilical artery doppler velocimetry. Am J Obstet Gynecol 2000; 182: 81-86

[70] Dubiel M, Gudmundsson S, Gunnarsson G et al. Middle cerebral artery velocimetry as a predictor of hypoxemia in fetuses with increased resistance to blood flow in the umbilical artery. Early Hum Dev 1997; 47: 177-184

[71] Morris RK, Say R, Robson SC et al. Systematic review and meta-analysis of middle cerebral artery Doppler to predict perinatal wellbeing. Eur J Obstet Gynecol Reprod Biol 2012; 165: 141-155

[72] Baschat AA, Cosmi E, Bilardo CM et al. Predictors of neonatal outcome in early-onset placental dysfunction. Obstet Gynecol 2007; 109: 253-261

[73] Severi FM, Bocchi C, Visentin A et al. Uterine and fetal cerebral Doppler predict the outcome of third-trimester small-for-gestational age fetuses with normal umbilical artery Doppler. Ultrasound Obstet Gynecol 2002; 19: $225-228$

[74] Hershkovitz R, Kingdom JC, Geary M et al. Fetal cerebral blood flow redistribution in late gestation: identification of compromise in small fetuses with normal umbilical artery Doppler. Ultrasound Obstet Gynecol 2000; 15: 209-212

[75] Cruz-Martinez R, Figueras F, Hernandez-Andrade E et al. Fetal brain Doppler to predict cesarean delivery for nonreassuring fetal status in term small-for-gestational-age fetuses. Obstet Gynecol 2011; 117: 618-626

[76] Rizzo G, Capponi A, Arduini D et al. The value of fetal arterial, cardiac and venous flows in predicting $\mathrm{pH}$ and blood gases measured in umbilical blood at cordocentesis in growth retarded fetuses. $\mathrm{Br}$ J Obstet Gynaecol 1995; 102: 963-969

[77] Morales-Rosello J, Khalil A. Fetal cerebral redistribution: a marker of compromise regardless of fetal size. Ultrasound Obstet Gynecol 2015; 46: 385-388

[78] Flood K, Unterscheider ], Daly S et al. The role of brain sparing in the prediction of adverse outcomes in intrauterine growth restriction: results of the multicenter PORTO Study. Am J Obstet Gynecol 2014; 211: 288.e1288.e5

[79] Khalil AA, Morales-Rosello J, Elsaddig M et al. The association between fetal Doppler and admission to neonatal unit at term. Am J Obstet Gynecol 2015; 213: 57.e1-57.e7

[80] Khalil AA, Morales-Rosello J, Morlando $\mathrm{M}$ et al. Is fetal cerebroplacental ratio an independent predictor of intrapartum fetal compromise and neonatal unit admission? Am J Obstet Gynecol 2015; 213: 54.e1-54.e10 
[81] Baschat AA, Gembruch U, Weiner CP et al. Qualitative venous Doppler waveform analysis improves prediction of critical perinatal outcomes in premature growth-restricted fetuses. Ultrasound Obstet Gynecol 2003; 22: $240-245$

[82] Turan OM, Turan S, Berg C et al. Duration of persistent abnormal ductus venosus flow and its impact on perinatal outcome in fetal growth restriction. Ultrasound Obstet Gynecol 2011; 38: 295-302

[83] Yagel S, Kivilevitch Z, Cohen SM et al. The fetal venous system, Part II: ultrasound evaluation of the fetus with congenital venous system malformation or developing circulatory compromise. Ultrasound Obstet Gynecol 2010; 36: 93-111

[84] Turan S, Turan OM, Berg C et al. Computerized fetal heart rate analysis, Doppler ultrasound and biophysical profile score in the prediction of acid-base status of growth-restricted fetuses. Ultrasound Obstet Gynecol 2007; 30: 750-756

[85] Baschat AA, Guclu S, Kush ML et al. Venous Doppler in the prediction of acid-base status of growth-restricted fetuses with elevated placental blood flow resistance. Am J Obstet Gynecol 2004; 191: 277-284

[86] Soothill PW, Ajayi RA, Campbell $S$ et al. Prediction of morbidity in small and normally grown fetuses by fetal heart rate variability, biophysical profile score and umbilical artery Doppler studies. Br J Obstet Gynaecol 1993; 100: 742-745

[87] Almstrom H, Axelsson O, Cnattingius S et al. Comparison of umbilicalartery velocimetry and cardiotocography for surveillance of small-forgestational-age fetuses. Lancet 1992; 340: 936-940

[88] German Society of Gynecology and Obstetrics (DGGG); Maternal Fetal Medicine Study Group (AGMFM); German Society of Prenatal Medicine and Obstetrics (DGPGM); German Society of Perinatal Medicine (DGPM). S1-Guideline on the use of CTG during pregnancy and labor. Long version - AWMF Registry No. 015/036. Geburtsh Frauenheilk 2014; 74: $721-732$

[89] Street P, Dawes GS, Moulden M et al. Short-term variation in abnormal antenatal fetal heart rate records. Am J Obstet Gynecol 1991; 165 : 515-523

[90] Dawes GS, Moulden M, Redman CW. Short-term fetal heart rate variation, decelerations, and umbilical flow velocity waveforms before labor. Obstet Gynecol 1992; 80: 673-678

[91] Anceschi MM, Ruozi-Berretta A, Piazze J] et al. Computerized cardiotocography in the management of intrauterine growth restriction associated with Doppler velocimetry alterations. Int J Gynaecol Obstet 2004; 86: $365-370$

[92] Dawes G, Meir Y], Mandruzzato GP. Computerized evaluation of fetal heart-rate patterns. J Perinat Med 1994; 22: 491-499

[93] Piazze J], Anceschi MM, Ruozzi Berretta A et al. The combination of computerized cardiotocography and amniotic fluid index for the prediction of neonatal acidemia at birth: a modified biophysical profile. J Matern Fetal Med 2001; 10: 323-327

[94] Serra V, Moulden M, Bellver J et al. The value of the short-term fetal heart rate variation for timing the delivery of growth-retarded fetuses. BJOG 2008; 115: 1101-1107

[95] Guzman ER, Vintzileos AM, Martins M et al. The efficacy of individual computer heart rate indices in detecting acidemia at birth in growth-restricted fetuses. Obstet Gynecol 1996; 87: 969-974

[96] Nijhuis IJ, ten Hof J, Mulder EJ et al. Fetal heart rate in relation to its variation in normal and growth retarded fetuses. Eur J Obstet Gynecol Reprod Biol 2000; 89: 27-33

[97] Ribbert LS, Snijders RJ, Nicolaides KH et al. Relation of fetal blood gases and data from computer-assisted analysis of fetal heart rate patterns in small for gestation fetuses. Br J Obstet Gynaecol 1991; 98: 820-823

[98] Serra V, Bellver J, Moulden M et al. Computerized analysis of normal fetal heart rate pattern throughout gestation. Ultrasound Obstet Gynecol 2009; 34: 74-79
[99] Visser GH, Sadovsky G, Nicolaides KH. Antepartum heart rate patterns in small-for-gestational-age third-trimester fetuses: correlations with blood gas values obtained at cordocentesis. Am J Obstet Gynecol 1990; 162: 698-703

[100] Lees CC, Marlow N, van Wassenaer-Leemhuis A et al. 2 year neurodevelopmental and intermediate perinatal outcomes in infants with very preterm fetal growth restriction (TRUFFLE): a randomised trial. Lancet 2015; 385: 2162-2172

[101] Baschat AA, Galan HL, Bhide A et al. Doppler and biophysical assessment in growth restricted fetuses: distribution of test results. Ultrasound Obstet Gynecol 2006; 27: 41-47

[102] Kaur S, Picconi JL, Chadha R et al. Biophysical profile in the treatment of intrauterine growth-restricted fetuses who weigh $<1000 \mathrm{~g}$. Am J Obstet Gynecol 2008; 199: 264.e1-264.e4

[103] Lalor JG, Fawole B, Alfirevic Z et al. Biophysical profile for fetal assessment in high risk pregnancies. Cochrane Database Syst Rev 2008; (1): CD000038. doi:10.1002/14651858.CD000038.pub2

[104] Roberts D, Dalziel S. Antenatal corticosteroids for accelerating fetal lung maturation for women at risk of preterm birth. Cochrane Database Syst Rev 2006; (3): CD004454. doi:10.1002/14651858. CD004454.pub2

[105] Doyle LW, Crowther CA, Middleton P et al. Magnesium sulphate for women at risk of preterm birth for neuroprotection of the fetus. Cochrane Database Syst Rev 2009; (1): CD004661. doi:10.1002/ 14651858.CD004661.pub3

[106] Marret S, Marpeau L, Zupan-Simunek V et al. Magnesium sulphate given before very-preterm birth to protect infant brain: the randomised controlled PREMAG trial*. BJOG 2007; 114: 310-318

[107] Rouse D], Hirtz DG, Thom E et al. A randomized, controlled trial of magnesium sulfate for the prevention of cerebral palsy. N Engl J Med 2008; 359: 895-905

[108] Crowther CA, Hiller JE, Doyle LW et al. Effect of magnesium sulfate given for neuroprotection before preterm birth: a randomized controlled trial. JAMA 2003; 290: 2669-2676

[109] Mittendorf R, Dambrosia J, Pryde PG et al. Association between the use of antenatal magnesium sulfate in preterm labor and adverse health outcomes in infants. Am J Obstet Gynecol 2002; 186: 1111-1118

[110] Vayssiere C, Sentilhes L, Ego A et al. Fetal growth restriction and intrauterine growth restriction: guidelines for clinical practice from the French College of Gynaecologists and Obstetricians. Eur J Obstet Gynecol Reprod Biol 2015; 193: 10-18

[111] Kehl S, Brade J, Schmidt U et al. Role of fetal abdominal circumference as a prognostic parameter of perinatal complications. Arch Gynecol Obstet 2011; 284: 1345-1349

[112] Hornemann A, Bohlmann MK, Diedrich $\mathrm{K}$ et al. Spontaneous uterine rupture at the 21st week of gestation caused by placenta percreta. Arch Gynecol Obstet 2011; 284: 875-878

[113] Aronow HD, Peyser PA, Eagle KA et al. Predictors of length of stay after coronary stenting. Am Heart J 2001; 142: 799-805

[114] Aronsson A, Bygdeman M, Gemzell-Danielsson K. Effects of misoprostol on uterine contractility following different routes of administration. Hum Reprod 2004; 19: 81-84

[115] [Anonym]. Committee Opinion No. 652 Summary: magnesium sulfate use in obstetrics. Obstet Gynecol 2016; 127: 195

[116] Liu J, Wang XF, Wang Y et al. The incidence rate, high-risk factors, and short- and long-term adverse outcomes of fetal growth restriction: a report from Mainland China. Medicine 2014; 93: e210

[117] Doctor BA, O'Riordan MA, Kirchner HL et al. Perinatal correlates and neonatal outcomes of small for gestational age infants born at term gestation. Am J Obstet Gynecol 2001; 185: 652-659

[118] Baschat AA. Doppler application in the delivery timing of the preterm growth-restricted fetus: another step in the right direction. Ultrasound Obstet Gynecol 2004; 23: 111-118 
[119] Group GS. A randomised trial of timed delivery for the compromised preterm fetus: short term outcomes and Bayesian interpretation. BJOG 2003; 110: 27-32

[120] Thornton JG, Hornbuckle J, Vail A et al. Infant wellbeing at 2 years of age in the Growth Restriction Intervention Trial (GRIT): multicentred randomised controlled trial. Lancet 2004; 364: 513-520

[121] Ferrazzi E, Bozzo M, Rigano S et al. Temporal sequence of abnormal Doppler changes in the peripheral and central circulatory systems of the severely growth-restricted fetus. Ultrasound Obstet Gynecol 2002; 19: 140-146

[122] Wilkinson AR, Ahluwalia J, Cole A et al. Management of babies born extremely preterm at less than 26 weeks of gestation: a framework for clinical practice at the time of birth. Arch Dis Child Fetal Neonatal Ed 2009; 94: F2-F5

[123] Unterscheider J, Daly S, Geary MP et al. Predictable progressive Doppler deterioration in IUGR: does it really exist? Am J Obstet Gynecol 2013; 209: 539.e1-539.e7

[124] Boers KE, Vijgen SM, Bijlenga D et al. Induction versus expectant monitoring for intrauterine growth restriction at term: randomised equivalence trial (DIGITAT). BMJ 2010; 341: c7087

[125] van Wyk L, Boers KE, van der Post JA et al. Effects on (neuro)developmental and behavioral outcome at 2 years of age of induced labor compared with expectant management in intrauterine growth-restricted infants: long-term outcomes of the DIGITAT trial. Am J Obstet Gynecol 2012; 206: 406.e1-406.e7

[126] Boers KE, van Wyk L, van der Post JA et al. Neonatal morbidity after induction vs expectant monitoring in intrauterine growth restriction at term: a subanalysis of the DIGITAT RCT. Am J Obstet Gynecol 2012; 206: 344.e1-344.e7

[127] Karsdorp VH, van Vugt JM, van Geijn HP et al. Clinical significance of absent or reversed end diastolic velocity waveforms in umbilical artery. Lancet 1994; 344: 1664-1668

[128] Forouzan I. Absence of end-diastolic flow velocity in the umbilical artery: a review. Obstet Gynecol Surv 1995; 50: 219-227

[129] Baschat AA, Weiner CP. Umbilical artery doppler screening for detection of the small fetus in need of antepartum surveillance. Am J Obstet Gynecol 2000; 182: 154-158

[130] Li H, Gudmundsson S, Olofsson P. Prospect for vaginal delivery of growth restricted fetuses with abnormal umbilical artery blood flow. Acta Obstet Gynecol Scand 2003; 82: 828-833

[131] Lin CC, Moawad AH, Rosenow PJ et al. Acid-base characteristics of fetuses with intrauterine growth retardation during labor and delivery. Am J Obstet Gynecol 1980; 137: 553-559

[132] Resnik R. Intrauterine growth restriction. Obstet Gynecol 2002; 99: 490-496

[133] Hornbuckle J, Vail A, Abrams KR et al. Bayesian interpretation of trials: the example of intrapartum electronic fetal heart rate monitoring. BJOG 2000; 107: 3-10

[134] Gulmezoglu AM, Hofmeyr G]. Bed rest in hospital for suspected impaired fetal growth. Cochrane Database Syst Rev 2000; (2): CD000034. doi:10.1002/14651858.CD000034

[135] Hofmeyr G], Lawrie TA, Atallah AN et al. Calcium supplementation during pregnancy for preventing hypertensive disorders and related problems. Cochrane Database Syst Rev 2014; (6): CD001059

[136] Say L, Gulmezoglu AM, Hofmeyr G]. Maternal nutrient supplementation for suspected impaired fetal growth. Cochrane Database Syst Rev 2003; (1): CD000148. doi:10.1002/14651858.CD000148

[137] Figueras F, Meler E, Eixarch E et al. Association of smoking during pregnancy and fetal growth restriction: subgroups of higher susceptibility. Eur J Obstet Gynecol Reprod Biol 2008; 138: 171-175

[138] Meher S, Duley L. Progesterone for preventing pre-eclampsia and its complications. Cochrane Database Syst Rev 2006; (4): CD006175. doi:10.1002/14651858.CD006175
[139] Say L, Gülmezoglu AM, Hofmeyr G]. Maternal oxygen administration for suspected impaired fetal growth. Cochrane Database Syst Rev 2003; (1): CD000137. doi:10.1002/14651858.CD000137

[140] Nozaki AM, Francisco RP, Fonseca ES et al. Fetal hemodynamic changes following maternal betamethasone administration in pregnancies with fetal growth restriction and absent end-diastolic flow in the umbilical artery. Acta Obstet Gynecol Scand 2009; 88: 350-354

[141] Gülmezoglu AM, Hofmeyr G]. Plasma volume expansion for suspected impaired fetal growth. Cochrane Database Syst Rev 2000; (2): CD000167. doi:10.1002/14651858.CD000167

[142] Newnham JP, Godfrey M, Walters B] et al. Low dose aspirin for the treatment of fetal growth restriction: a randomized controlled trial. Aust N Z J Obstet Gynaecol 1995; 35: 370-374

[143] von Dadelszen P, Dwinnell S, Magee LA et al. Sildenafil citrate therapy for severe early-onset intrauterine growth restriction. BJOG 2011; 118 : 624-628

[144] Lausman A, Kingdom J, Maternal Fetal Medicine Committee. Intrauterine growth restriction: screening, diagnosis, and management. J Obstet Gynaecol Can 2013; 35: 741-757

[145] Abalos E, Duley L, Steyn DW. Antihypertensive drug therapy for mild to moderate hypertension during pregnancy. Cochrane Database Syst Rev 2014; (2): CD002252

[146] Gülmezoglu AM, Hofmeyr G]. Betamimetics for suspected impaired fetal growth. Cochrane Database Syst Rev 2001; (4): CD000036. doi:10.1002/14651858.CD000036

[147] Schleussner E, Lehmann T, Kahler C et al. Impact of the nitric oxide-donor pentaerythrityl-tetranitrate on perinatal outcome in risk pregnancies: a prospective, randomized, double-blinded trial. J Perinat Med 2014; 42: 507-514

[148] Härtel C, Herting E. Nachsorge von Frühgeborenen. Pädiatrische Praxis 2010; 75: 3-20

[149] Bujold E, Roberge S, Lacasse Y et al. Prevention of preeclampsia and intrauterine growth restriction with aspirin started in early pregnancy: a meta-analysis. Obstet Gynecol 2010; 116: 402-414

[150] Henderson JT, Whitlock EP, O'Connor E et al. Low-dose aspirin for prevention of morbidity and mortality from preeclampsia: a systematic evidence review for the U.S. Preventive Services Task Force. Ann Intern Med 2014; 160: 695-703

[151] Roberge S, Nicolaides KH, Demers S et al. Prevention of perinatal death and adverse perinatal outcome using low-dose aspirin: a meta-analysis. Ultrasound Obstet Gynecol 2013; 41: 491-499

[152] Magee LA, Duley L. Oral beta-blockers for mild to moderate hypertension during pregnancy. Cochrane Database Syst Rev 2003; (3): CD002863. doi:10.1002/14651858.CD002863

[153] Khoury J, Henriksen T, Christophersen B et al. Effect of a cholesterollowering diet on maternal, cord, and neonatal lipids, and pregnancy outcome: a randomized clinical trial. Am J Obstet Gynecol 2005; 193 : 1292-1301

[154] Ota E, Tobe-Gai R, Mori R et al. Antenatal dietary advice and supplementation to increase energy and protein intake. Cochrane Database Syst Rev 2012; (9): CD000032

[155] Pena-Rosas JP, De-Regil LM, Garcia-Casal MN et al. Daily oral iron supplementation during pregnancy. Cochrane Database Syst Rev 2015 (7): CD004736

[156] Ota E, Mori R, Middleton P et al. Zinc supplementation for improving pregnancy and infant outcome. Cochrane Database Syst Rev 2015; (2): CD000230

[157] Makrides M, Crosby DD, Bain E et al. Magnesium supplementation in pregnancy. Cochrane Database Syst Rev 2014; (4): CD000937

[158] De-Regil LM, Palacios C, Lombardo LK et al. Vitamin D supplementation for women during pregnancy. Cochrane Database Syst Rev 2016; (1): CD008873 
[159] Dodd JM, McLeod A, Windrim RC et al. Antithrombotic therapy for improving maternal or infant health outcomes in women considered at risk of placental dysfunction. Cochrane Database Syst Rev 2013; (7): CD006780

[160] Duffett L, Rodger M. LMWH to prevent placenta-mediated pregnancy complications: an update. Br J Haematol 2015; 168: 619-638

[161] Rodger MA, Carrier M, Le Gal G et al. Meta-analysis of low-molecularweight heparin to prevent recurrent placenta-mediated pregnancy complications. Blood 2014; 123: 822-828

[162] Lumley J, Chamberlain C, Dowswell T et al. Interventions for promoting smoking cessation during pregnancy. Cochrane Database Syst Rev 2009; (3): CD001055. doi:10.1002/14651858.CD001055.pub3

[163] McCowan LM, Dekker GA, Chan E et al. Spontaneous preterm birth and small for gestational age infants in women who stop smoking early in pregnancy: prospective cohort study. BMJ 2009; 338: b1081
[164] Lindqvist PG, Molin J. Does antenatal identification of small-for-gestational age fetuses significantly improve their outcome? Ultrasound Obstet Gynecol 2005; 25: 258-264

[165] Marsal K. Obstetric management of intrauterine growth restriction. Best Pract Res Clin Obstet Gynaecol 2009; 23: 857-870

[166] Gaudineau A. [Prevalence, risk factors, maternal and fetal morbidity and mortality of intrauterine growth restriction and small-for-gestational age]. J Gynecol Obstet Biol Reprod (Paris) 2013; 42: 895-910

[167] Cnossen JS, Morris RK, ter Riet G et al. Use of uterine artery Doppler ultrasonography to predict pre-eclampsia and intrauterine growth restriction: a systematic review and bivariable meta-analysis. CMAJ 2008; 178: 701-711

[168] Stampalija T, Gyte GM, Alfirevic Z. Utero-placental Doppler ultrasound for improving pregnancy outcome. Cochrane Database Syst Rev 2010; (9): CD008363. doi:10.1002/14651858.CD008363.pub2 


\section{Guideline Program}

\section{Editors}

Leading Professional Medical Associations

\section{Ty}

German Society of Gynecology and Obstetrics (Deutsche Gesellschaft für Gynäkologie und Geburtshilfe e. V. [DGGG])

Head Office of DGGG and Professional Societies Hausvogteiplatz 12

DE-10117 Berlin

info@dggg.de

http://www.dggg.de/

\section{President of DGGG}

Prof. Dr. Birgit Seelbach-Göbel

Universität Regensburg

Klinik für Geburtshilfe und Frauenheilkunde

St. Hedwig-Krankenhaus Barmherzige Brüder

Steinmetzstraße 1-3

DE-93049 Regensburg

\section{DGGG Guidelines Representative}

Prof. Dr. med. Matthias W. Beckmann

Universitätsklinikum Erlangen

Frauenklinik

Universitätsstraße 21-23

DE-91054 Erlangen

\section{Guidelines Coordination}

Dr. med. Paul Gaß, Tobias Brodkorb, Marion Gebhardt Universitätsklinikum Erlangen

Frauenklinik

Universitätsstraße 21-23

DE-91054 Erlangen

fk-dggg-leitlinien@uk-erlangen.de

http://www.dggg.de/leitlinienstellungnahmen

\section{OEGGC}

Austrian Society of Gynecology and Obstetrics (Österreichische Gesellschaft für Gynäkologie und Geburtshilfe [OEGGG])

Innrain 66A

AT-6020 Innsbruck stephanie.leutgeb@oeggg.at

http://www.oeggg.at

\section{President of OEGGG}

Prof. Dr. med. Petra Kohlberger

Universitätsklinik für Frauenheilkunde Wien

Währinger Gürtel 18-20

AT-1180 Wien

\section{OEGGG Guidelines Representative}

Prof. Dr. med. Karl Tamussino

Universitätsklinik für Frauenheilkunde und Geburtshilfe Graz

Auenbruggerplatz 14

AT-8036 Graz

gynécologie
suisse

Swiss Society of Gynecology and Obstetrics (Schweizerische Gesellschaft für Gynäkologie und Geburtshilfe [SGGG])

Gynécologie Suisse SGGG

Altenbergstraße 29

Postfach 6

CH-3000 Bern 8

sekretariat@sggg.ch

http://www.sggg.ch/

President of SGGG

Dr. med. David Ehm

FMH für Geburtshilfe und Gynäkologie

Nägeligasse 13

$\mathrm{CH}-3011$ Bern

\section{SGGG Guidelines Representative}

Prof. Dr. med. Daniel Surbek

Universitätsklinik für Frauenheilkunde

Geburtshilfe und feto-maternale Medizin

Inselspital Bern

Effingerstraße 102

$\mathrm{CH}-3010$ Bern 